Nowoczesne Systemy Zarządzania

Zeszyt 14 (2019), nr 3 (lipiec-wrzesień)

ISSN 1896-9380, s. 15-26

Modern Management Systems

Volume 14 (2019), No. 3 (July-September)

ISSN 1896-9380, pp. 15-26
Instytut Organizacji i Zarządzania

Wydział Bezpieczeństwa, Logistyki i Zarządzania

Wojskowa Akademia Techniczna

w Warszawie

Institute of Organization and Management Faculty of Security, Logistics and Management Military University of Technology

\title{
Understanding the cyber-physical-social-intentional Workforce 4.0
}

\section{Analiza cyberfizyczno-społeczno-intencjonalnej Siły Roboczej 4.0}

\author{
Matthew E. Gladden \\ Anglia Ruskin University \\ Lord Ashcroft International Business School
}

\begin{abstract}
The widespread application of Industry 4.0 technologies relating to social robotics, $\mathrm{Al}$, the Internet of Things (IoT), ubiquitous computing, and advanced human-computer interfaces is giving rise to a growing range of "cyber-physical" entities. By building on established definitions of such entities, this text formulates a novel conceptual framework for understanding the emerging Workforce 4.0 as a specialized type of "cyber-physical-social-intentional system". Attention is given to the heterogeneous agency, functional decentralization, technological posthumanization, and planned architectures or spontaneously self-organizing topologies manifested by Workforce 4.0. It is shown how such a workforce is situated within the context of cyber-physical space, a cyber-physical organization, cyber-physical ecosystems, a cyber-physical society, and the larger cyber-physical world.
\end{abstract}

Keywords: Management 4.0, Workforce 4.0, cyber-physical systems, cyber-physical-social-intentional systems, technological posthumanization.

Abstrakt. Rosnące zastosowanie technologii Przemysłu 4.0, związanych z robotyką społeczną, sztuczną inteligencją, Internetem rzeczy, przetwarzaniem rozpowszechnionym i zaawansowanymi interfejsami człowiek - komputer, wywołuje powstawanie coraz większej liczby "cyberfizycznych" jednostek. Opierając się na ustalonych definicjach takich jednostek, niniejszy tekst proponuje nowe ramy koncepcyjne wyłaniającej się Siły Roboczej 4.0 jako szczególnego rodzaju „systemu cyberfizyczno-społeczno-intencjonalnego”. Zwraca się uwagę na niejednorodność sprawczości, posthumanizację technologiczną, funkcjonalną decentralizację i celowo zaplanowane architektury albo spontanicznie samoorganizujące się topologie manifestowane przez Siłę Roboczą 4.0. Pokazany jest sposób, w jaki taka siła robocza działa w kontekście przestrzeni cyberfizycznej, organizacji cyberfizycznej, ekosystemów cyberfizycznych, społeczeństwa cyberfizycznego i szerszego cyberfizycznego świata.

Słowa kluczowe: Zarządzanie 4.0, Siła Robocza 4.0, systemy cyberfizyczne, systemy cyberfizyczno-społeczno-intencjonalne, posthumanizacja technologiczna. 


\section{Introduction}

As emerging technologies relating to social robotics, artificial intelligence (AI), the Internet of Things (IoT), ubiquitous computing, and advanced human-computer interfaces (HCIs) permeate a growing number of organizations, workplaces are increasingly becoming "cyber-physical environments" in which processes of gathering and analyzing data, making decisions, and acting are embedded in a distributed network of human and artificial agents. This text formulates a conceptual framework for understanding how such change is engendering a Workforce 4.0 that constitutes a particular type of "cyber-physical-social-intentional system", and it develops recommendations that highlight ways in which organizational decision-makers can respond to the unique challenges and opportunities of Workforce 4.0.

\section{Methodology}

This study has employed a purposive non-probability sampling method and cross-sectional time horizon for gathering, analyzing, and synthesizing secondary data in the form of $30+$ scholarly publications that investigate cyber-physical entities, as discussed below. As understood within the methodological spectrum discussed by A. Bryman (2016) and J.W. Creswell and J.D. Creswell (2018), the study utilizes an inductive approach, qualitative methodology, and phenomenologically based research philosophy, which are capable of generating results with significant trustworthiness, credibility, relevance, and confirmability (Lincoln, Guba, 1985).

\section{Conceptualizing the cyber-physical-social-intentional system}

Before focusing on Workforce 4.0 as a particular type of cyber-physical-social-intentional system, it will be helpful to investigate the nature of "cyber-physical entities" (Mordecai, Chapman, Dori, 2013) more generally.

\subsection{The cyber-physical object}

A key concept is that of the "cyber-physical object" (Petrolo, Loscri, Mitton, 2016). Such an object has a dual nature (Mordecai, Chapman, Dori, 2013): in physical space, it occupies volume as a physical object, while in computational, digital, virtual, or informational space, it serves as a networked locus of distributed embedded computation. Such objects demonstrate "cyber-physical interdependencies" (Marashi, Sarvestani, Hurson, 2018) between their physical and informatic elements, a "cyber-physical convergence" of computational and physical processes (Wang, 
Zheng, 2014), or a deeper "cyber-physical integration" of physical objects with their virtual counterparts in cyberspace (Saldivar, Li, Chen et al., 2015).

Ordinary physical products may undergo a process of "cyber-physical augmentation" by which they become cyber-physical objects and acquire new "cyber-physical functionalities" (Vroom, Horváth, 2014). Such cyber-physical objects may be small and simple "cyber-physical devices" (Park, Young, Chen et al., 2013) or, for example, larger and more complex "cyber-physical vehicles" (Wang, Li, Yi et al., 2016) or "cyber-physical buildings" (Dobbs, 2015) that give rise to smart environments.

\subsection{The cyber-physical system (CPS)}

Wang, Vuran, and Goddard (2008, p. 1) explain that "Cyber-Physical Systems (...) are large-scale interconnected systems of heterogeneous components that are envisioned to provide integration of computation with physical processes" (Gill, 2008, p. 3) states that within such systems, "Components are networked at every scale. Computing is 'deeply embedded' into every physical component (...)", and "The behavior of a cyber-physical system is a fully-integrated hybridization of computational (logical) and physical action". By participating in wider processes of networked, embedded, real-time computation distributed throughout an environment's diverse objects, a cyber-physical object exists as part of such a larger cyber-physical system (CPS).

\subsection{The cyber-physical-social system (CPSS)}

The networked, distributed components of a cyber-physical system continually transmit information between themselves. When such communication involves natural language, facial expressions, gestures, or other social behaviors, the CPS becomes a cyber-physical-social system (CPSS). A CPSS typically involves human beings as the entities that add the system's social dimension. For a business, a CPSS might include human employees and (potential) customers who perform "cyber-physical-social behaviours" within cyber-physical spaces (Ren, Tomko, Salim et al., 2018).

Technically, though, a CPSS need not include human members, as long as it includes artificial agents capable of social behavior. For example, a CPSS might comprise members of a robotic swarm that interact socially (e.g., using gestures, vocalizations, or other signals that convey meaning). Through their interactions, the components of a CPSS can create "cyber-physical social networks" whose topologies follow their components' social connections (Ganti, Tsai, Abdelzaher, 2008).

\subsection{The cyber-physical-social-intentional system}

A contemporary CPSS that includes artificial agents but no human members manifests a certain limited (artificial) "intelligence"; indeed, it might constitute 
a "cyber-physical-cognitive system" that can function autonomously (Ivancevic, Reid, Pilling, 2017). However, it lacks the kinds of conscious awareness, sapience, conscience, and "intentionality" (understood in a phenomenological sense (Sokolowski, 2000) that distinguish the typical adult human being from extant forms of AI.

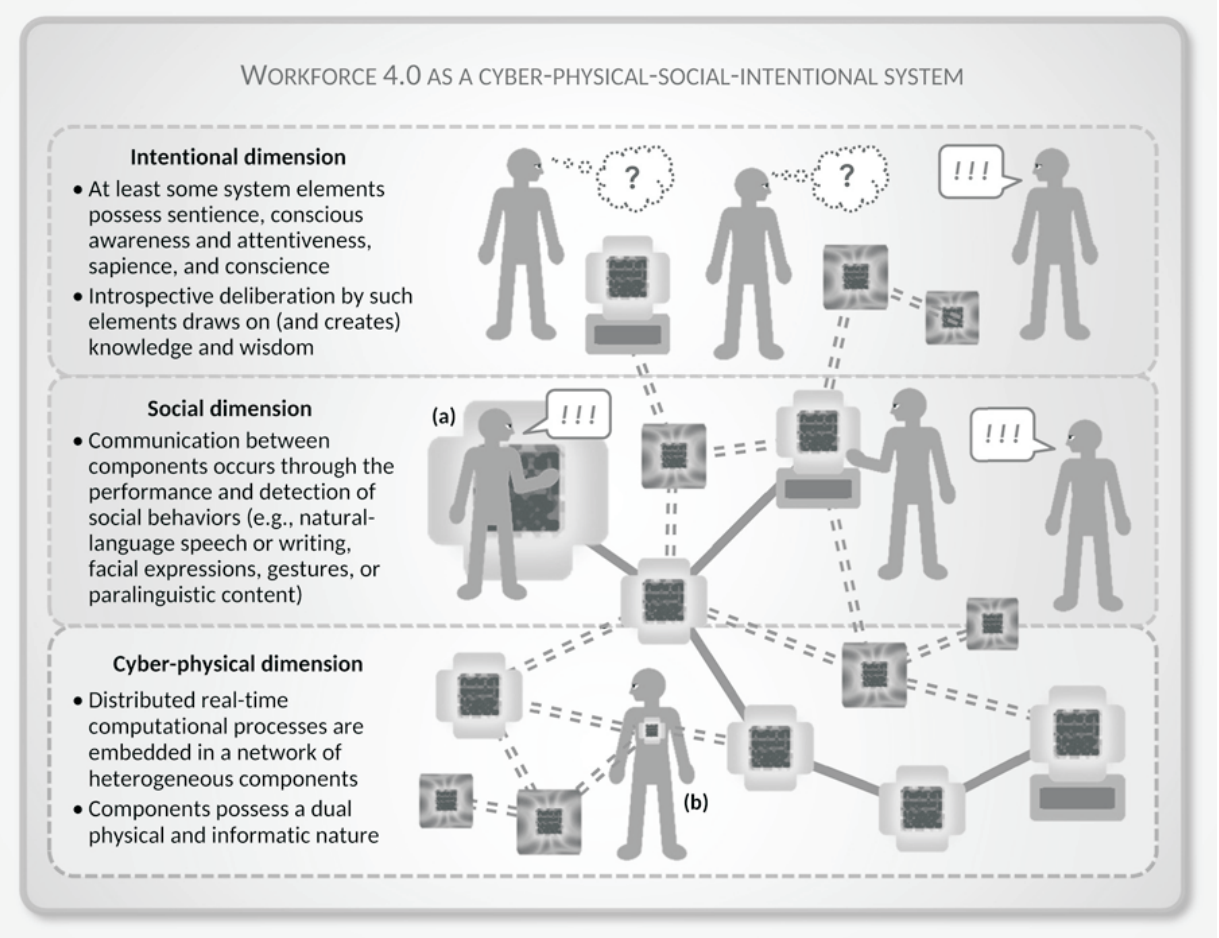

Fig. 1. An emerging "Workforce 4.0" as a particular type of cyber-physical-social-intentional system; this example includes (a) an employee immersed in a VR-facilitated interactive virtual environment and (b) an employee possessing a networked implanted neuroprosthetic device

Source: own research and design

Only when human beings are incorporated into a CPS or CPSS does it become what we might refer to as a "cyber-physical-social-intentional system" (CPSIS). Such a system operates within a "cyber-physical-social-thinking space" (or CPST space) that expands cyber-physical-social space by extension into the "Internet of Thoughts/ Ideas" or "Internet of Thinking" (Ning, Liu, 2015, p. 4). Such a system encompasses not only data or information, but "collaborative human wisdom" that transcends "cyber-physical-social space limitations" (Ning, Liu, 2015, p. 4). The philosophical anthropology and systems theory developed by phenomenologist Roman Ingarden $(1974,1987)$ provide one possible tool for conceptually linking the intentional and systems-theoretical dimensions of such a system (Gladden, 2019). 


\section{Workforce 4.0 as a cyber-physical-social-intentional system}

If an organization has extensively implemented Industry 4.0 technologies, its workforce will constitute a unique type of cyber-physical-social-intentional system, as depicted in figure 1 . We can refer to such an entity as the "cyber-physical-social-intentional workforce" (CPSIW) or, more simply, Workforce 4.0.

\subsection{The heterogeneity of agency in Workforce 4.0}

Workforce 4.0 is a collection of human workers as they are incorporated into and operate within a particular organizational cyber-physical-social-intentional system. If such workers were removed from that system - with its many artificial agents and computational components - they would no longer be able to function as a "workforce" of the sort necessary for an Industry 4.0 organization.

Workforce 4.0 thus encompasses the whole of the CPSIS within which human workers are embedded, with its heterogeneous collection of intelligent embodied agents, both human and artificial; this distinguishes Workforce 4.0 from earlier industrialized workforces in which natural biological human beings constituted the primary or sole intelligent agents who gathered information, made decisions, and acted to advance an organization's goals. Within Workforce 4.0, natural biological human workers are joined as intelligent embodied agents by diverse synthetic entities like social robots, online chatbots, smart vehicles, smart buildings, and other artificially intelligent systems - as well as by human beings who have become integrated into their organization's electronic information systems through neurocybernetic augmentation (Gladden, 2017). Workforce 4.0 constitutes a varied (and even bewildering) menagerie of such entities. It can thus be understood as a "technologically posthumanized" workforce, insofar as it includes members other than "natural" biological human beings who contribute as intelligent social actors to the workforce's structure, activity, and meaning (Gladden, 2017, 2018, 2019).

\subsection{Architecture of the cyber-physical-social-intentional workforce}

Typically, the human components of a CPSIW lend a certain stability and familiarity to its architecture, while the artificial components add diversity and mutability. Some cyber-physical systems possess a particular "cyber-physical architecture" (Xiao-Le, Hong-Bin, Su, Li-Na, 2012) purposefully chosen from among many possible designs within "cyber-physical design space" (Fitzgerald, Gamble, Payne, Lam, 2017) and evaluated through the use of "cyber-physical testbeds" (Yardley, Berthier, Nicol, Sanders, 2013) or simulations (Rasmussen, Yang, Nielsen, Dong, 2018).

Organizations with rapidly changing ad hoc cyber-physical networks operating in poorly documented, uncontrollable natural environments (e.g., combat forces or 
disaster response teams) may generate a "cyber-physical terrain" in which cyber-physical elements "are in constant motion with an unpredictable pattern of node-to-node connectivity" (Thompson, Harang, 2017, p. 23). Some cyber-physical networks - and especially, large and complex ones - are self-organizing (Smirnov, Sandkuhl, Shilov, 2013), possessing spontaneously arising architectures that can potentially be "extracted" (Huang, Davis, 2018) by analyzing a network's unique "cyber-physical topology" (Weaver, Chen, Rogers et al., 2013).

\section{Context of the cyber-physical-social-intentional workforce}

The emerging Workforce 4.0 operates in the context of larger cyber-physical entities that shape and are influenced by it, some of which are depicted in figure 2 . We consider such entities below.

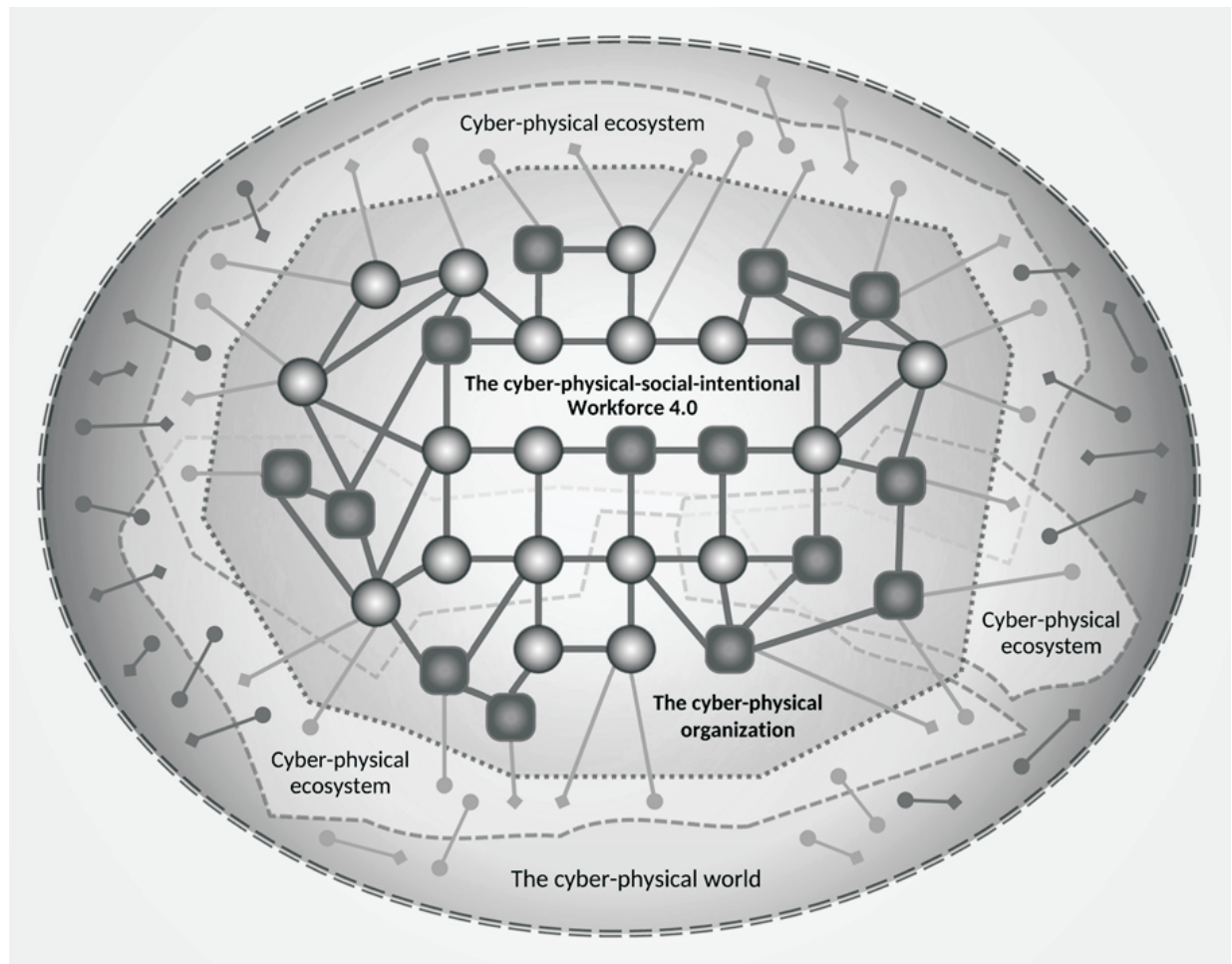

Fig. 2. Workforce 4.0 in its larger cyber-physical context; this workforce combines a planned core architecture with a spontaneously self-organizing peripheral network topology 


\subsection{Cyber-physical spaces}

Tsigkanos, Kehrer, and Ghezzi (2016, p. 1011) note that "We increasingly live in cyber-physical spaces: spaces that are both physical and digital, and where the two aspects are intertwined". When human beings or social robots enter and engage with such spaces, they become "cyber-physical social spaces" in which future forms of AI may be able to learn continually (Wang, Zhang, Wang, 2018). A CPSIW often operates within such a "smart cyber-physical environment" (Seiger, Keller, Niebling, Schlegel, 2015) that may not be part of the workforce per se, but which interacts with (and ideally supports) it.

\subsection{The cyber-physical organization}

A cyber-physical-social-intentional workforce exists for and as part of a particular cyber-physical organization (although components of the CPSIW might simultaneously belong to multiple organizations' workforces). Such a cyber-physical organization can be understood as a heterogeneous assemblage of intelligent embodied agents (1) united in the pursuit of a common goal and (2) forming a network in which computational mechanisms for real-time communication and control are deeply embedded in the agents, their tools, and their workspace (Gladden, 2017, p. 140). In the context of Industry 4.0, cyber-physical organizations are often based around "cyber-physical manufacturing systems" (Yu, Ouyang, Li, Peng, 2017) or "cyber-physical production systems" (Monostori, 2014); however, the range of Industry 4.0 organizations is expanding beyond such "factories of the future" to include organizations operating in a broad range of domains (Marrella, Mecella, Halapuu, Sardina, 2015, p. 59).

\subsection{Cyber-physical ecosystems}

A cyber-physical-social-intentional workforce exists within one or more "cyber-physical ecosystems of people, processes, and things" (Moldovan, Copil, Dustdar, 2018, p. 76) that may geographically span local, national, and international levels and include vast numbers of current or potential customers, competitors, suppliers, and other stakeholders, along with their own cyber-physical devices and environments. If a decentralized cyber-physical ecosystem (e.g., an eHealth ecosystem) achieves a critical mass" of participants, its "self-organizing mechanisms" may allow it to dynamically evolve in a manner analogous to that of a natural biological ecosystem - with varying types of human and artificial members playing the roles of "digital species" that drive the ecosystem's development through competition for resources and the digital-physical equivalent of biological mutualism, parasitism, or other forms of interaction (Benedict, Schlieter, 2015, pp. 233-234; Guedria, Lamine, Pingaud, 2014). A sufficiently large Workforce 4.0 may give rise to its own internal cyber-physical ecosystem. 


\subsection{Cyber-physical society}

Monostori (2014, p. 11) argues that when cyber-physical systems are harnessed to enhance human quality of life, they can give rise to a "cyber-physical society, which already includes human, social, cultural spheres as well, above the physical- and cyber spaces". Similarly, Zhuge (2010, p. 1) writes, that "With the rapid development of information technology, the cyber space is connecting physical space, social space and mental space to form a new world - Cyber Physical Society". A "cyber-physical society" may thus be understood as a conventional human society that has evolved to incorporate the new realities of cyberspace. The Japanese Government's groundbreaking Society 5.0 initiative represents a proactive effort to facilitate the development of such a cyber-physical society (Gladden, 2019).

\subsection{The cyber-physical world}

Together, the phenomena described above give rise to a new "cyber-physical age" (Patel, Lei, Liu et al., 2017), "cyber-physical world" (Wan, Chen, Leung, 2014), or "cyber-physical reality" (Minchev, Dukov, 2016) that transcends the uses of cyber-physical systems in particular Industry 4.0 enterprises and encompasses all aspects of human life and all activity of the planet's networked computing systems and devices - in a manner reminiscent of the global "noosphere" of human thought (and its embodiments) foreseen by Pierre Teilhard de Chardin, SJ (1966), and of the heterogeneous and horizontally spreading "rhizome" of Deleuze and Guattari (1987). In such a world, each example of Workforce 4.0 accesses, inhabits, and constitutes a subset of the global "cyber-physical web" - which is an unfathomably vast warehouse of electronically digitalized information (Shou, Wu, 2013) and information stored within the biological computers of human workers' bodies - and extends and enhances that cyber-physical web with the knowledge and wisdom held within workers' minds.

\section{Practical recommendations and conclusion}

By analyzing the account of Workforce 4.0 and its organizational context presented above, it is possible to formulate at least three concrete recommendations for decision-makers within organizations that are undergoing or considering the shift to a Workforce 4.0 model.

First, managers of organizations that are adopting elements of Workforce 4.0 (either inadvertently or by strategic design) must analyze the unique benefits, drawbacks, and risks accompanying such a transformation and formulate appropriate responses. For example, the Workforce 4.0 paradigm may yield increased productivity - but at the cost of decreasing the predictability and controllability of an organization's workforce, due 
to the fact that a sufficiently large and complex CPSIS may give rise to a digital-physical computational ecosystem whose dynamics, decisions, and actions are no longer easily centrally planned or controlled (Benedict, Schlieter, 2015, pp. 233-234; Guedria, Lamine, Pingaud, 2014). From a formal and legal perspective, Workforce 4.0 might still possess a conventional hierarchical organizational structure in which human workers are supervised by higher-ranking employees, and artificially intelligent agents or devices are not considered part of the personnel structure at all; however, on the practical level of everyday operations and information flow, the patterns of decision-making, acting, and reporting manifested by Workforce 4.0 are likely to be radically decentralized and potentially difficult to monitor or control. An organization must determine how to avoid or best mitigate the manifold risks associated with such a situation.

Second, executives of organizations implementing Workforce 4.0 must be ready to break down longstanding departmental barriers and create new transdisciplinary departments or functions that reflect the novel characteristics of Workforce 4.0. Because of the hybrid biological-electronic nature of Workforce 4.0, it cannot be successfully managed using only practices from HR management or IT management; insights from both are required. New teams for "human and artificial resource management" may thus be needed to drive the strategic development of Workforce 4.0's complex technological and social-intentional aspects and human employees' immersion in new forms of "cyber-physical computing" (Burgio, Alvarez, Ayguadé et al., 2016).

Third, managers of Workforce 4.0 organizations will need to reassess which skills and capacities are necessary or desirable in its employees: successfully manipulating or controlling a cyber-physical-social-intentional environment is not (primarily) about knowing programming languages or possessing programming skills; it is often about being able to physically steer or socially influence the behavior of interactive cyber-physical systems in real time in order to accomplish desired tasks. In that regard, individuals who are (for example) proficient video game players and esports participants - especially those familiar with natural user interfaces or AR/ VR gaming - may be better able to intuitively understand, navigate, and manipulate the cyber-physical environment of Workforce 4.0 than individuals who possess more conventional computer programming skills.

The ongoing adoption of Industry 4.0 paradigms and technologies is expected to affect ever more workforces. This text has proposed a framework for understanding such transformation as engendering a Workforce 4.0 that constitutes a special type of cyber-physical-social-intentional system operating in a broader cyber-physical world. By formulating new approaches for conceptualizing Workforce 4.0 and highlighting some of the concrete ways in which organizational decision-makers can respond to its challenges and opportunities, it is hoped that this text can contribute to the creation of future workforces that are not only effective and efficient but that also appropriately recognize the distinct abilities and needs of their human members and artificial cyber-physical elements. 


\section{BIBLIOGRAPHY}

[1] Benedict M., Schlieter H., 2015, Governance Guidelines for Digital Healthcare Ecosystems, [in:] D. Hayn, G. Schreier, E. Ammenwerth, A. Hörbst (eds.), eHealth2015 - Health Informatics Meets eHealth. Innovative Health Perspectives: Personalized Health, ISO Press, Amsterdam, pp. 233-240.

[2] Bryman A., 2016, Social Research Methods, Oxford University Press, Oxford.

[3] Burgio P., Alvarez C., Ayguadé E., Filgueras A., Jimenez-Gonzalez D., Martorell X., Navarro N., Giorgi R., 2016, Simulating Next-Generation Cyber-Physical Computing Platforms, "Ada User Journal", Vol. 37, No. 1, pp. 59-63.

[4] Creswell J.W., Creswell J.D., 2018, Research Design: Qualitative, Quantitative, and Mixed Methods Approaches, SAGE Publications, Los Angeles.

[5] Deleuze G., Guattari F., 1987, A Thousand Plateaus, University of Minnesota Press, Minneapolis.

[6] Dоввs J., 2015, Toward a Streamlined Software Tool Chain for Cyber-Physical Buildings (doctoral dissertation in Mechanical Engineering), Cornell University, Ithaca.

[7] Fitzgerald J., Gamble C., Payne R., Lam, B., 2017, Exploring the Cyber-Physical Design Space, "INCOSE International Symposium", Vol. 27, No. 1, pp. 371-385.

[8] Ganti R.K., Tsai Y.E., Abdelzaher T.F., 2008, Senseworld: Towards Cyber-Physical Social Networks, [in:] Proceedings of the 7th International Conference on Information Processing in Sensor Networks, IEEE Computer Society Press, Washington, pp. 563-564.

[9] Gill H., 2008, From Vision to Reality: Cyber-Physical Systems (presentation), [in:] HCSS National Workshop on New Research Directions for High Confidence Transportation CPS: Automotive, Aviation, and Rail, NITRD, National Science Foundation, 18-20 November, Washington, pp. 1-29.

[10] Gladden M.E., 2017, Strategic Management Instruments for Cyber-Physical Organizations: Technological Posthumanization as a Driver of Strategic Innovation, "International Journal of Contemporary Management", Vol. 16, No. 3, pp. 139-155.

[11] Gladden M.E., 2018, Sapient Circuits and Digitalized Flesh: The Organization as Locus of Technological Posthumanization, Defragmenter Media, Indianapolis.

[12] Gladden M.E., 2019, Who Will Be the Members of Society 5.0? Towards an Anthropology of Technologically Posthumanized Future Societies, "Social Sciences", Vol. 8, No. 5.

[13] Guédria W., Lamine E., Pingaud H., 2014, Health Systems Interoperability: Analysis and Comparison, [in:] MOSIM 2014, 10ème Conférence Francophone de Modélisation, Optimisation et Simulation, November, Nancy, France.

[14] Huang H., Davis K., 2018, Extracting Substation Cyber-Physical Architecture Through Intelligent Electronic Devices' Data, [in:] The 2018 IEEE Texas Power and Energy Conference (TPEC), IEEE, Piscataway Township, pp. 1-6.

[15] Ingarden R., 1974, Über die kausale Struktur der realen Welt: Der Streit um die Existenz der Welt III, Max Niemeyer Verlag, Tübingen.

[16] Ingarden R., 1987, O odpowiedzialności i jej podstawach ontycznych, [in:] Ingarden R., Ksiązeczka o człowieku, Wydawnictwo Literackie, Kraków, pp. 71-169.

[17] Ivancevic V.G., Reid D.J., Pilling M.J., 2017, Mathematics of Autonomy: Mathematical Methods for Cyber-Physical-Cognitive Systems, World Scientific Publishing, Singapore.

[18] Lincoln Y.S., Guba E.G., 1985, Naturalistic Inquiry, Sage, Beverly Hills.

[19] Liu Z., Yang D., Wen D., Zhang W., Mao W., 2011, Cyber-Physical-Social Systems for Command and Control, "IEEE Intelligent Systems", Vol. 26, No. 4, pp. 92-96. 
[20] Marashi K., Sarvestani S.S., Hurson A.R., 2018, Consideration of Cyber-Physical Interdependencies in Reliability Modeling of Smart Grids, "IEEE Transactions on Sustainable Computing", Vol. 3, No. 2, pp. 73-83.

[21] Marrella A., Mecella M., Halapuu P., Sardina S., 2015, Automated Process Adaptation in Cyber-Physical Domains with the SmartPM System (Short Paper), [in:] 2015 IEEE 8th International Conference on Service-Oriented Computing and Applications (SOCA), IEEE, 19-21 October, Rome, pp. 59-64.

[22] McGrew W., Dandass Y., 2009, Engineering FUTURE CYBER-PHYSICAL ENERGY SYSTEMS: Challenges, Research Needs, and Roadmap, [in:] Power Symposium. North American. 41st 2009 (NAPS 2009), IEEE, 4-6 October, Starkville, pp. 1-6.

[23] Minchev Z., Dukov G., 2016, Emerging Hybrid Threats Modelling \& Exploration in the New Mixed Cyber-Physical Reality, [in:] Proceedings of the Eighth International Conference on Business Information Security, BISEC, Belgrade, pp. 13-17.

[24] Moldovan D., Copil G., Dustdar S., 2018, Elastic Systems: Towards Cyber-Physical Ecosystems of People, Processes, And Things, “Computer Standards \& Interfaces”, No. 57, pp. 76-82.

[25] Monostori L., 2014, Cyber-Physical Production Systems: Roots, Expectations and R\&D Challenges, "Procedia CIRP”, No. 17, pp. 9-13.

[26] Mordecai Y., Chapman C., Dori D., 2013, Conceptual Modelling of Physical-Informatical Essence Duality of Cyber-Physical Entities, IEEE International Conference on Systems, Man, and Cybernetics, 13-16 October, IEEE, Manchester.

[27] Morris T.H., Srivastava A.K., Reaves B., Pavurapu K., Abdelwahed S., Vaughn R., Ning H., Liu H., 2015, Cyber-Physical-Social-Thinking Space Based Science and Technology Framework for the Internet of Things, "Science China Information Sciences", Vol. 58, No. 3, pp. 1-19.

[28] Park Y.L., Young D., Chen B.R., Wood R.J., Nagpal R., Goldfield, E.C., 2013, Networked Bio-Inspired Modules for Sensorimotor Control of Wearable Cyber-Physical Devices, [in:] 2013 International Conference on Computing, Networking and Communications (ICNC), IEEE, 28-31 January, San Diego, pp. 92-96.

[29] Patel C., Lei Y., Liu L., Vernica R., Fan J., Short B., Liu J., Simske, S.J., 2017, Learning in the 21st Century Cyber-Physical Age, "APSIPA Transactions on Signal and Information Processing", No. 6.

[30] Petrolo R., Loscri V., Mitton N., 2016, Cyber-Physical Objects as Key Elements for a Smart Cyber-City, [in:] Management of Cyber Physical Objects in the Future Internet of Things, Springer, Cham, pp. 31-49.

[31] Rasmussen T.B., Yang G., Nielsen A.H., Dong Z., 2018, Effects of Centralized and Local PV Plant Control for Voltage Regulation in LV Feeder Based on Cyber-Physical Simulations, "Journal of Modern Power Systems and Clean Energy", Vol. 6, No. 5, pp. 979-991.

[32] Ren Y., Tomko M., Salim F.D., Chan J., Sanderson M., 2018, Understanding the Predictability of User Demographics from Cyber-Physical-Social Behaviours in Indoor Retail Spaces, "EPJ Data Science", Vol. 7, No. 1.

[33] Saldivar A.A.F., Li Y., Chen W.N., Zhan Z.H., Zhang J., Chen L.Y., 2015, Industry 4.0 with Cyber-Physical Integration: A Design and Manufacture Perspective, [in:] ICAC '15: 21st International Conference on Automation and Computing, IEEE, 11-12 September, Glasgow, pp. 1-6.

[34] Seiger R., Keller C., Niebling F., Schlegel T., 2015, Modelling complex and flexible processes for smart cyber-physical environments, "Journal of Computational Science", No. 10, pp. 137-148.

[35] Shou L., Wu S., 2013, Supporting Efficient Social Media Search in Cyber-Physical Web, "IEEE Data Eng. Bull., Vol. 36, No. 3, pp. 83-90. 
[36] Smirnov A., Sandkuhl K., Shilov N., 2013, Multilevel Self-Organisation of Cyber-Physical Networks: Synergic Approach, "International Journal of Integrated Supply Management", Vol. 8, No. 1-3, pp. 90-106.

[37] Sокоцоwsкi R., 2000, Introduction to Phenomenology, Cambridge University Press, Cambridge.

[38] Teilhard de Chardin P., SJ, 1966, The Vision of the Past, Harper and Row, New York.

[39] Thompson B., Harang, R., 2017, Identifying Key Cyber-Physical Terrain, [in:] IWSPA '17: Proceedings of the 3rd ACM on International Workshop on Security and Privacy Analytics, ACM, New York, pp. 23-28.

[40] Tsigkanos C., Kehrer T., Ghezzi C., 2016, Architecting Dynamic Cyber-Physical Spaces, “Computing", Vol. 98, No. 10, pp. 1011-1040.

[41] Vroom R.W., Horváth I., 2014, Cyber-Physical Augmentation: An Exploration, [in:] Tools and Methods of Competitive Engineering. Digital Proceedings of the 10th International Symposium on Tools and Methods of Competitive Engineering, TMCE, Budapest, Hungary, 19-23 May, Delft University of Technology, Delft.

[42] Wan J., Chen M., Leung V.C., 2014, M2M Communications in the Cyber-Physical World, "Machineto-Machine Communications: Architectures, Technology, Standards, and Applications", No. 1.

[43] Wang F.Y., Zhang J.J., Wang X., 2018, Parallel Intelligence: Toward Lifelong and Eternal Developmental AI and Learning in Cyber-Physical-Social Spaces, "Frontiers of Computer Science", No. 12, pp. 401-405.

[44] Wang H., Li Q., Yi F., Li Z., Sun L., 2016, Influential Spatial Facility Prediction Over Large Scale Cyber-Physical Vehicles in Smart City, "EURASIP Journal on Wireless Communications and Networking", No. 1.

[45] Wang H., Zheng Z., 2014, Collective Self-Adaptive Software Architecture Specification: Understanding Uncertainty in Cyber-Physical Convergence, "Journal of Computers", Vol. 9, No. 4, pp. 802-811.

[46] Wang Y., Vuran M.C., Goddard S., 2008, Cyber-Physical Systems in Industrial Process Control, "ACM SIGBED Review", Vol. 5, No. 1, pp. 1-2.

[47] Weaver G.A., Cheh C., Rogers E.J., Sanders W.H., Gammel D., 2013, Toward a Cyber-Physical Topology Language: Applications to NERC CIP Audit, [in:] SEGS '13: Proceedings of the First ACM Workshop on Smart Energy Grid Security, ACM, New York, pp. 93-104.

[48] Xiao-Le W., Hong-Bin H., Su D., Li-Na C., 2012, A Service-Oriented Architecture Framework for Cyber-Physical Systems, "Recent Advances in Computer Science and Information Engineering”, Vol. 126, No. 3, pp. 671-676.

[49] Yardley T., Berthier R., Nicol D., Sanders W.H., 2013, Smart Grid Protocol Testing Through Cyber-Physical Testbeds, [in:] 2013 IEEE PES Innovative Smart Grid Technologies (ISGT), IEEE, Piscataway Township, pp. 1-6.

[50] Yu Z., Ouyang J., Li S., Peng X., 2017, Formal Modeling and Control of Cyber-Physical Manufacturing Systems, "Advances in Mechanical Engineering", Vol. 9, No. 10, pp. 1-12.

[51] Zhuge H., 2010, Cyber Physical Society, [in:] SKG '10: Proceedings of the 2010 Sixth International Conference on Semantics, Knowledge and Grids, IEEE Computer Society, Washington, pp. 1-8. 